ings parts. Excision can often be effected from below after disarticulating the coccyx, but for bigger cysts situated higher up an abdominal or abdomino-perineal approach is necessary. ${ }^{3} 4$

Chordomas arise from remnants of the fetal notochord. They may occur in either sex at any age but are most often seen in men past middle life. They slowly enlarge over the years, causing sacral or sciatic pain and later interfering with the sphincters or sexual function. In $10 \%$ of cases distant metastases are found. On rectal palpation the tumour is felt as an elastic, sometimes lobulated, swelling. $X$-ray examination shows circular or oval areas of translucency in the sacrum corresponding to the lesion; there may also be trabeculation or calcification. Biopsy discloses characteristic vacuolated mucus-containing cells. Chordomas have usually been treated by excision through a sacral approach, but are often found to be beyond the scope of surgical removal, or they may subsequently recur, so that most patients eventually die of the condition. ${ }^{17}$ In resecting chordomas surgeons have usually been careful to preserve the uppermost two pieces of sacrum together with the third sacral nerve on at least one side to safeguard sphincter function. ${ }^{7}$ But recently S. A. Localio $^{8}$ has employed an abdomino-perineal technique and removed all but the first sacral segment without detriment. These tumours are generally considered to be radioinsensitive, but Sir Brian Windeyer has reported excellent long-term results with supervoltage irradiation. ${ }^{9}$

${ }^{1}$ Freier, D. T., Stanley, J. C., and Thompson, N. W., Surgery, Gynecology and Obstetrics, 1971, 132, 681

2 Mayo, C. W., Baker, G. S., and Smith, L. R., Mayo Clinic Proceedings, $1958,28,616$.

${ }^{3}$ Swinton, N. W., and Lehman, G., Surgical Clinics of North America, 1958, 38, 849 .

- Jackman, R. J., Clark, P. Le M., and Smith, N. D., fournal of the American Medical Association, 1951, 145, 956.

${ }^{3}$ Gaston, E. A., Diseases of the Colon and Rectum, 1969, 12, 241.

- Killen, D. A., and Jackson, L. M., Archives of Surgery, 1963, 88, 425.

7 McCarty, C. S., Waugh, J. M., Mayo, C. W., and Coventry, M. B., Mayo Clinic Proceedings, 1952, 27, 73.

Localio, S. A., Frances, K. C., and Rossano, P. G., Annals of Surgery, 1967, 166, 394.

- Windeyer, B. W., Proceedings of the Royal Society of Medicine, 1959, 52, 1088.

\section{Cholera in Spain}

The arrival of cholera in Spain is not unexpected, for the disease has been edging into the Mediterranean littoral for some time. Sporadic cases also appeared last year in Great Britain $^{1}$ and in Czechoslovakia. ${ }^{2}$ The Briton who brought the disease back to this country had been on holiday in Tunisia.

Though cholera is unlikely to become established in epidemic form in Britain or the Continent of Europe, the possibility of outbreaks must be taken seriously. This is especially so in some popular holiday lands where the incidence of endemic typhoid already shows the standards of sanitation to be below those enforced in Britain. The question of who should be vaccinated must be settled quickly, and the public also needs to be clearly informed that the protection obtained is poorer than with most other types of immunization. Travellers have become accustomed to believing that $\mathrm{a}$ jab in the arm gives virtually complete protection against a disease, but this is not true of cholera. In one study the protection was reported to be only $85 \%$ effective three months after two injections and practically nil after six months. ${ }^{3}$ They must therefore be told plainly how to weigh the risk of infection against the benefit of a holiday or whatever the purpose of their journey may be. Some guidance on the choice of food and drink might also appropriately be offered. Though the infection is generally waterborne, faecal-oral transmission through the intermediary of food does also occur.

It is evident from press reports that a misconception about the severity of the E1 Tor disease exists among lay people. This is not a "mild" form of cholera. The disease it causes is as severe as the classical forms in earlier epidemics. But what can be said is that modern methods of treatment centered on the replacement of fluid and electrolytes ${ }^{4}$ have enormously improved the prognosis for patients in whom the disease is diagnosed in time.

1 British Medical fournal, 1970, 4, 61.
2 British Medical fournal, 1970, 4, 376.
Mosley, W. H., et al., Bulletin of the World Health Organization, 1969,
40, 187.
'British Medical fournal, 1970, 4, 2 .

\section{New Chairman of Council}

At the Council Meeting after the Annual Representative Meeting at Leicester Mr. Walpole Lewin was elected Chairman of Council for a period of three years in succession to Dr. Ronald Gibson. Mr. Lewin, who is 55 , is consultant neurosurgeon at Addenbrooke's Hospital, Cambridge. Since 1968 he has been chairman of the Central Committee for Hospital Medical Services and deputy chairman of the Joint Consultants Committee. He is on the council of the Royal College of Surgeons of England, a member of the G.M.C., and on the Central Health Services Council. He is a Fellow of Darwin College, Cambridge, and of University College, London.

Dr. Gibson retires from the chair with the good wishes and gratitude of all his colleagues. He has rendered outstanding service to the Association and the profession it represents. Elected Chairman of Council in 1966 in succession to $\mathrm{Mr}$. J. R. Nicholson-Lailey, his term of office spanned five exceptionally busy years. Hardly was he in the chair when the Prime Minister of the day announced the Government's intention to freeze wages and salaries. This was the prelude to recurrent economic crises which culminated so far as the profession was concerned in last year's resignation of the Review Body. Parliament passed the Abortion Act, with provisions contrary to advice given by the B.M.A. and the Royal College of Obstetricians and Gynaecologists. The Seebohm report appeared, followed quickly by legislation. The Medical Acts were amended, giving the G.M.C. new powers, a step which led to the crisis of confidence with that council. Successive Governments' changing views on the future of the Health Service were made known in the two Green Papers and the Consultative Document, and now there is the Industrial Relations Bill, which will affect all who work in the Service. In addition to actions of Government this quinquennium saw the publication of the Todd report on medical education, as well as constitutional reform within the Association designed to improve the balance of representation by craft. In all these events doctors were vitally concerned, and the Association, led by its Chairman of Council, put forward the profession's views. Dr. Gibson will be remembered specially for his firm and courageous leadership, his accessibility and success as roving ambassador for the Association, and for a breadth of vision which put equal value on the promotion of the medical and allied sciences and the maintenance of the profession's honour and interests. 